Journal Dimensie Management and Public

Sector

https://hdpublication.com/index.php/jdmps

Volume 2, Issue 2, 2021, page 025-032

\title{
Market Reaction to the Announcement of Covid-19: Event Study in Indonesia
}

Ramadhana Tri Hardiyanti ${ }^{1}$, Ratna Septiyanti ${ }^{1}$, Fitra Dharma ${ }^{1}$

${ }^{1}$ Accounting Science, Faculty of Economics and Business, University of Lampung, Indonesia

*Corresponding Author: Ramadhana Tri Hardiyanti

Email: ramadhanatrihe0@gmail.com

Received: March 7, 2021

Revised: April 8, 2021

Accepted: April 29, 2021

\section{Abstract}

The aim of this research is to determine whether there are significant differences in abnormal return and trading volume activity in the time pre and post the national declaration of the first Coronavirus Disease-19 case in Indonesia announced by President Joko Widodo's on March 2, 2020. Secondary data was used to perform this study. The study's population consisted of all companies listed on the Indonesia Stock Exchange in 2020, with a purposive sample size of 327 companies. The time frame used in this analysis was 11 days, 5 days pre the first Coronavirus Disease-19 case was announced ( $t-5)$, the day of the declaration or $t 0$, and 5 days post the first Coronavirus Disease-19 case was announced $(t+5)$ and the estimation period used in this study is 10 days, from $t-15$ to $t-5$ pre the event date. The Wilcoxon Signed Rank Test was used to analyze the data. Post the national declaration of the first Coronavirus Disease-19 case in Indonesia, there were discrepancies in abnormal returns and trading volume operation, according to the findings.

Keywords: Abnormal Return, Coronavirus Disease-19, Event Study, Trading Volume Activity

\section{Introduction}

An event contains information that can affect conditions in the capital market. Information obtained from an event must be absorbed properly by investors because it can help in making investment decisions. The stock market reaction to the Coronavirus Disease-19 pandemic was the first occurrence of a world market crash triggered by a health crisis. The stock market index reacts to events very quickly. The Coronavirus Disease-19 pandemic is an epidemic that has caused market conditions to react, the Coronavirus Disease-19 virus started in Wuhan City, China at the end of 2019. The spread of the outbreak occurred very quickly and paralyzed financial systems around the world. Coronavirus Disease-19 has a broad impact on the financial sector, especially on the stock market.

The stock market in China (Broadstock et al., 2020) initially did not react to the ongoing events depicted with a CSI3000 value of around 5,200, but post the State's policy to lock down the stock market was closed and reopened in February with an index CSI3000 experienced a sharp decline from a value of 5,200 to 4,800. The Chinese stock market fluctuated rapidly by 5,000 at the end of February. The Coronavirus Disease-19 outbreak was announced to be a global pandemic by the World Health Organization in March so that the global market experienced a large decline 
and China's CSI3000 experienced a sharp drop to 4,600.

Based on the latest data from the Indonesia Stock Exchange (IDX), the downturn in the stock market has had a major impact on Indonesia and has almost the same cycle as China. The composite stock price index $(\mathrm{JCl})$ in January was stable with a value of 6,323 and experienced a sharp decline at the end of February with a value of 5,452. At the time of the declaration of the global pandemic in March, the $\mathrm{JCl}$ had fallen again by a value of 4,895 . In line with the increasing rate of Coronavirus Disease-19 transmission in Indonesia, the $\mathrm{JCl}$ hit its lowest point at the end of March with a value of 3,937. The $\mathrm{JCl}$ decreased in almost all sectors, the largest decline was the financial sector index at $2.77 \%$, the plantation sector fell $2.01 \%$, the mining sector fell $1.76 \%$, the basic industrial sector fell $1.26 \%$, the construction and property sector eroded $1.11 \%$, miscellaneous industry sector fell $1.09 \%$, trade, and services sector fell $0.82 \%$, and the manufacturing sector fell $0.41 \%$.

Previous research conducted by (Sambuari et al., 2020) found that this event did not contain information that caused the market to not react. This event did not contain information, so there was no reaction and did not have a major impact on market activities in the capital market, particularly in the food and beverage sub-sector. Another study conducted by (Rahmawati et al., 2020) found that there was no significant difference in the average abnormal return of shares in the hotel, restaurant, and tourism sub-sector companies pre-post the implementation of the PSBB policy in Indonesia. In contrast to the research conducted by (Sumiari and Putri, 2020), there are differences in market reactions as reflected in the stock price on the LQ45 index. Issuers that have had a positive reaction are those outside the banking and property sectors. According to research by (Febriyanti, 2020), there is a substantial difference in abnormal returns and trading volume behavior pre and post the first case of Coronavirus Disease-19 patients in Indonesia was announced. These findings suggest that post the declaration of the first case of Coronavirus Disease-19 patients in Indonesia, the market sent out negative signals to investors, causing the stock price of LQ-45 companies to fall and investors to sell shares of LQ-45 companies.

\section{Hypothesis Development}

If information is a good signal, investors will be motivated to carry out stock trading so that trading volume in the market will increase as a result of positive market reactions, and vice versa (Suwardjono, 2010). The Coronavirus Disease-19 pandemic is one of the events that impacted various subsectors in the world, this virus caused major changes to the capital market. The first case of Coronavirus Disease-19 in Indonesia is a warning of bad news that could lead to a drop in stock prices and a reduction in business returns. The daily increase in the number of confirmed cases and deaths due to Coronavirus Disease-19 adversely affects the stock returns of all companies in China (Al-Awadhi et al., 2020). There is an inverse relationship between the increase in the number of confirmed cases and stock returns. Investor's pessimistic sentiment led to a decline in stock abnormal returns.

$H_{1}$ : There is a difference in abnormal returns pre and post the first Coronavirus Disease-19 case in Indonesia was announced.

The declaration of the first Coronavirus Disease-19 case in Indonesia was interpreted as bad news for investors, causing panic post an increasing number of victims tested positive for Coronavirus 
Disease-19, prompting panic selling by investors. The declaration of the first case of Coronavirus Disease-19 in Indonesia as an initial event that attacks various economic subsectors in Indonesia will certainly have a lot of effect on the decline in stock prices and trading volume activity. Trading volume activity is an important factor in determining the sustainability of a company's business. High volume trading activity is also an indicator that the company is performing well. The higher the number of shares that are traded, this indicates that investors have high confidence in trading shares in the company. The higher the number of shares traded on the stock market, this indicates that investors believe in the company's performance, and the end, the share price will increase (Indarti and Purba, 2011).

$\mathrm{H}_{2}$ : There are differences in trading volume activity pre and post the declaration of the first Coronavirus Disease-19 case in Indonesia.

\section{Methods}

This type of research is an event study using numerical data. The data used in this study are historical secondary data. In this study, the objects of research are abnormal returns and trading volume activity in all companies listed on the Indonesia Stock Exchange in 2020. Sources of data used in this study were obtained from the sites www.idx.co.id and https://finance.yahoo.com. Population is a generalization area consisting of objects and subjects that have certain qualities and characteristics that are applied by researchers to study and then draw conclusions (Sugiyono, 2012). The population in this study was 713 companies listed on the Indonesia Stock Exchange in 2020.Sampling in this study using a purposive sampling technique. The use of the purposive sampling method in this study is that all companies listed on the IDX in 2020 have the criteria for companies listed on the IDX in 2020, companies that are actively traded for five days pre and five days post the declaration of the first Coronavirus Disease-19 case, do not issue a policy others such as dividends, rights issues, bonus shares, and other stock declarations during the observation period, complete company data is available for analysis needs.

\section{Results and Discussion}

The results of descriptive statistical testing of the variable abnormal return, trading volume activity, and declaration of Coronavirus Disease-19 are presented in the table below.

Table 1. Descriptive Analysis

\begin{tabular}{|l|c|c|c|c|c|}
\hline \multicolumn{1}{|c|}{ Variable } & N & Minimum & Maximum & Mean & $\begin{array}{c}\text { Std. } \\
\text { Deviation }\end{array}$ \\
\hline $\begin{array}{l}\text { CAR pre the declaration of the first } \\
\text { Coronavirus Disease-19 case }\end{array}$ & 327 & $-32,5297$ & 20,0642 & $-5,207800$ & 8,1219237 \\
\hline $\begin{array}{l}\text { CAR post the declaration of the first } \\
\text { Coronavirus Disease-19 case }\end{array}$ & 327 & $-38,9622$ & 24,2070 & $-6,095438$ & 9,7444155 \\
\hline $\begin{array}{l}\text { TVA pre the declaration of the first } \\
\text { Coronavirus Disease-19 case }\end{array}$ & 327 & 0,000000 & 3,954456 & 0,0186508 & 0,2189196 \\
\hline $\begin{array}{l}\text { TVA post the declaration of the first } \\
\text { Coronavirus Disease-19 case }\end{array}$ & 327 & 0,000001 & 5,644087 & 0,0247539 & 0,312389 \\
\hline
\end{tabular}

Source: Primary data, 2021. 
Based on table 1 The results of the descriptive study show that, prior to the declaration of the first Coronavirus Disease-19 case in Indonesia, the minimum accumulated abnormal return (CAR) was -32.5297 owned by PT Jasa Armada Indonesia Tbk and the maximum CAR was 20.0642 which owned by PT Nusantara Inti Corpora Tbk, with an average value of -5.207800 , this means that the average difference between actual returns and expected returns in the period pre is 5.207800 and a standard deviation of 8.1219237. Following the declaration of the first Coronavirus Disease-19 case in Indonesia, a period of time passed, the minimum CAR was 38.9622 owned by PT Jasa Armada Indonesia Tbk and the maximum CAR was 24.2070 owned by PT Nusantara Inti Corpora Tbk, with an average value of - 6,095438, The standard deviation is 9.7444155, and the average difference between the real return and the predicted return in the time post is -6.095438 .

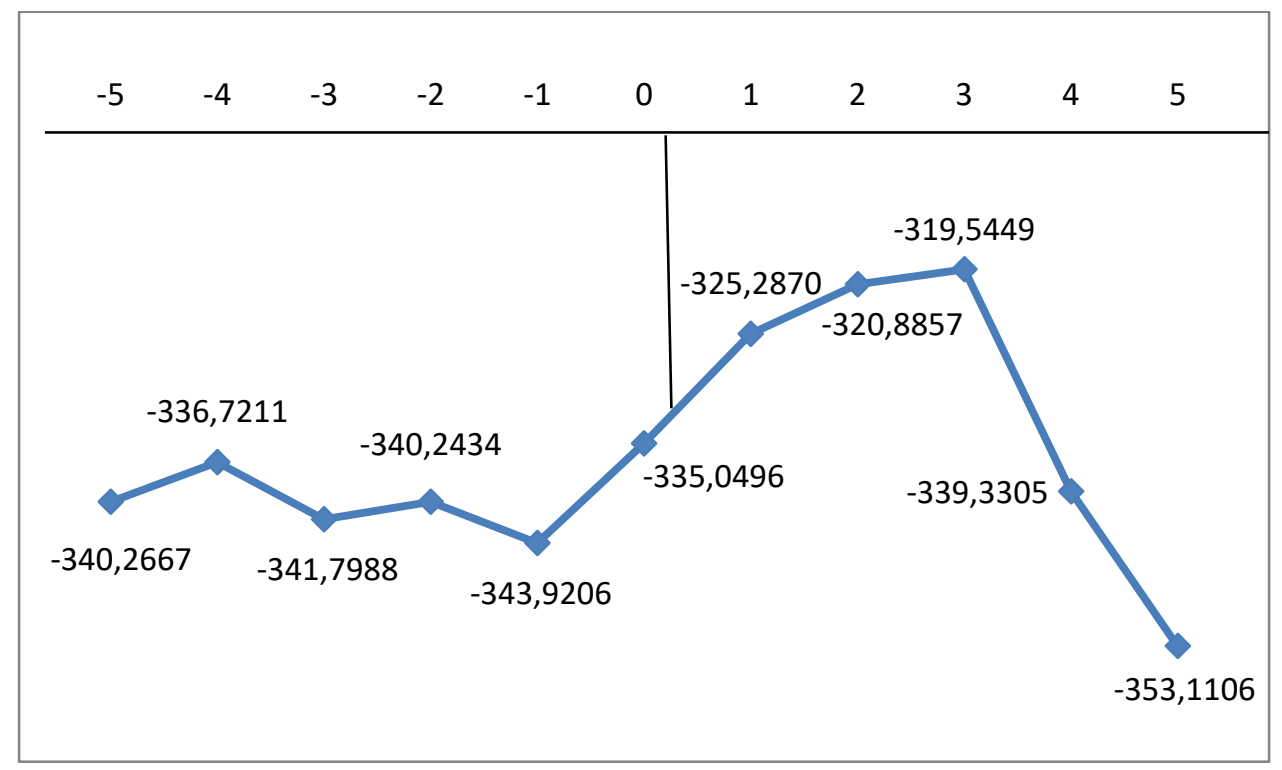

Figure 1 . The cumulative daily abnormal return pre and post the declaration of the first Coronavirus Disease-19 case in Indonesia

Source: Primary data, 2021

It can be seen in Figure 1 that the daily CAR is negative from d-5 or the fifth day pre it reaches $h+5$ post the declaration of the first Coronavirus Disease-19 case in Indonesia. However, at $h+1$, $h+2$ and $h+3$ the CAR has increased. Then it can be seen that at $h+4$ and $h+5$ the daily CAR has decreased significantly. As compared to the time pre the declaration of the first Coronavirus Disease-19 case in Indonesia, the regular CAR movement trend shows movements that appear to fluctuate in the period leading up to the incident, with a noticeable increase on the $h+1$ day post the declaration of the first Coronavirus Disease-19 case in Indonesia. From this figure, it can be concluded that the daily stock CAR in the study period shows a significant reaction in the period post the event, seen from the CAR movement pattern which shows a significant decrease and increases in the period post the declaration. Based on the average value of abnormal returns pre and post the event, it shows that the period pre the declaration of the first Coronavirus Disease-19 case in Indonesia has a smaller value than the period post the declaration, although at $h+4$ and $h+5$ it has decreased again, it can be concluded that the declaration of the first DOI: https://doi.org/10.48173/jdmps.v2i2.89 
Coronavirus Disease-19 case in Indonesia contains positive information or good news and negative or bad news that can make the capital market react to an increase or decrease in the abnormal return rate.

The minimum of trading volume activity is 0.000000 owned by the Finance sub-sector company, namely PT Minna Padi Investama Sekuritas Tbk. and the maximum of trading volume activity of 3,954456 owned by the property and real estate sub-sector company, namely PT DMS Propertindo Tbk., with an average value of 0.0186508 and a standard deviation of 0.2189196. This means that the average trading volume activity in the period pre the declaration of the first Coronavirus Disease-19 case in Indonesia was 0.0186508. Following the declaration of the first Coronavirus Disease-19 case in Indonesia, a period of time passed, the minimum trading volume activity was 0.000001 owned by the Finance sub-sector company, namely PT Bank Panin Dubai Syariah Tbk., And the maximum trading volume activity was 5.644087 owned by sub-sector companies. Property and Real Estate, namely PT DMS Propertindo Tbk., With an average value of 0.0247539 and a standard deviation of 0.312389 . This means that the average trading volume in the period post the declaration of the first Coronavirus Disease-19 case in Indonesia was 0.0247539 .

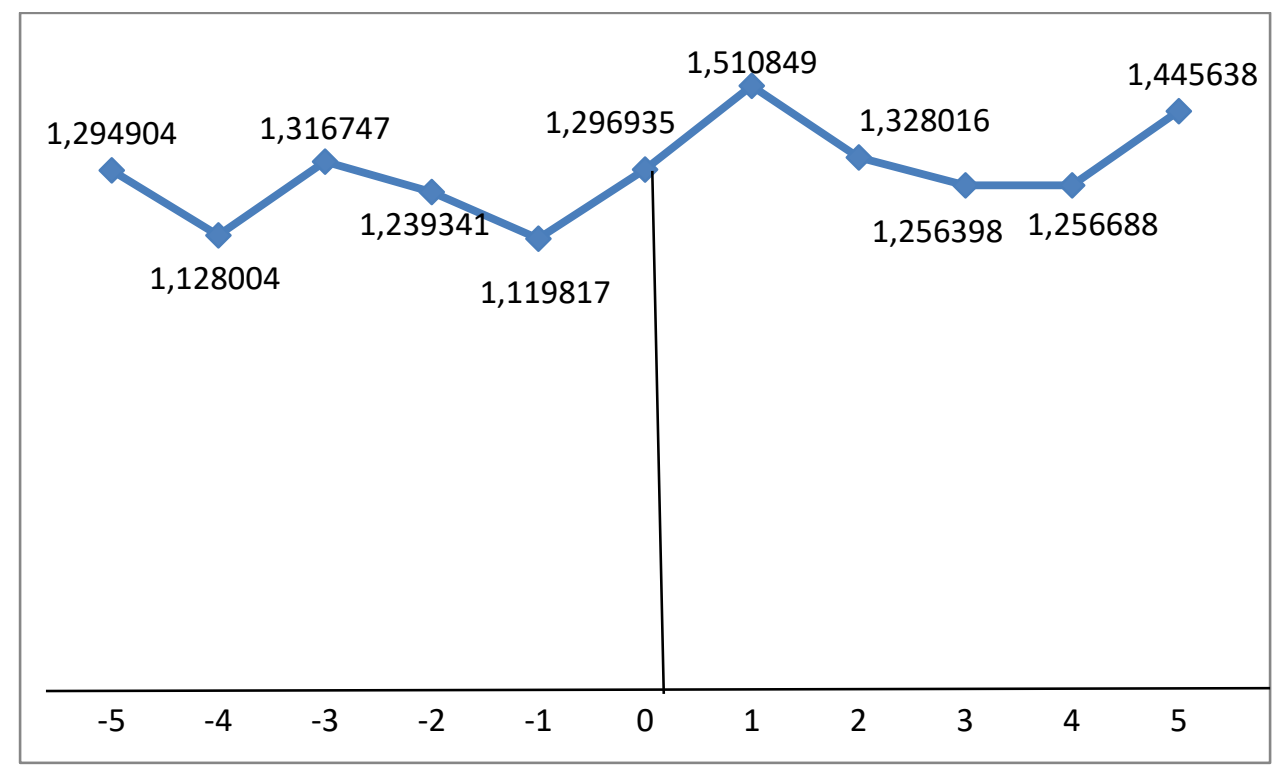

Figure 2. The Cumulative Daily Trading volume activity pre and post the declaration of the first Coronavirus Disease-19 case in Indonesia

Source: Primary data, 2021.

The trading volume activity or daily trading volume activity at the declaration of the first Coronavirus Disease-19 case in Indonesia is positive, as shown in Figure 2. In the eleven days, 5 days pre and 5 days post the declaration of the first Coronavirus Disease-19 case in Indonesia, the highest TVA values were obtained, namely at $h+1$ and $h+5$ and the lowest TVA value at $h$ 1. The movement pattern of TVA in the declaration of the inaugural Coronavirus Disease-19 case in Indonesia showed fluctuating movements both pre the event and post the declaration. Based on the movement pattern of trading volume activity, which showed a significant decrease or 
increase and tended to fluctuate in the period pre and post the declaration of the first Coronavirus Disease-19 case in Indonesia, it can be concluded that trading volume activity during the study period showed a significant reaction. The average share TVA value in the period following the declaration of the inaugural Coronavirus Disease-19 case in Indonesia is higher than the period prior to the occurrence, indicating that stock transactions in the capital market increased post the declaration.

There are limitations to this study, this study only compares two variables abnormal return and trading volume activity, using a fairly short event window, which is only 5 days pre and post 5 days of the declaration of the first Coronavirus Disease-19 case in Indonesia, only covers the capital market in Indonesia, calculating the abnormal return using the market model. Suggestions for further studies add research variables to see market reactions in a broad sense, such as variable changes in stock prices and market capitalization, use a longer observation period in the hope that the research results will be more accurate, not only covering the capital market in Indonesia but also the market capital in Asia so that the results can include the impact in various countries, the calculation of abnormal returns using other models, examples mean adjusted model and/or the market adjusted model.

\section{Hypothesis Testing}

\section{Wilcoxon Signed Ranks Test}

The results of the Wilcoxon signed ranks test of the variable abnormal return, trading volume activity, and declaration of Coronavirus Disease-19 are presented in the table below.

Table 2. Results Wilcoxon Signed Ranks Test

\begin{tabular}{|l|c|c|c|}
\hline & N & Z & Asymp. Sig. (2-tailed) \\
\hline $\begin{array}{l}\text { AR pre and post the declaration of the first } \\
\text { Coronavirus Disease-19 case. }\end{array}$ & 327 & $-9,438^{c}$ & 0,000 \\
\hline $\begin{array}{l}\text { TVA pre and post the declaration of the first } \\
\text { Coronavirus Disease-19 case. }\end{array}$ & 327 & $-2,300^{\mathrm{b}}$ & 0,021 \\
\hline
\end{tabular}

Source: Primary data, 2021.

Based on table 2. the results of the Wilcoxon Signed Ranks Test above, It can be concluded that the abnormal return has an Asymp significance value pre and post the declaration of the first Coronavirus Disease-19 case in Indonesia. Sig. (two-tailed) of 0.000 less than 0.05 or $<5 \%$, This means that the hypothesis indicates that abnormal returns have knowledge material, and that abnormal returns occur pre and post the first Coronavirus Disease-19 case in Indonesia is announced for all companies listed on the Indonesia Stock Exchange in 2020 and the research hypothesis or $\mathrm{H}_{1}$ is "supported". In line with research conducted by (Hindayani, 2020) there are differences in abnormal returns and cumulative abnormal returns before and after the announcement of the first Covid-19 case in Indonesia because the Covid-19 pandemic affects almost all industrial subsectors and makes investors feel pessimistic. This result is in line with the signaling theory which states that every action (event) can provide a signal to a market, either in the form of a positive signal or a negative signal, if an event contains strong information, the market will react quickly. The declaration of the first Coronavirus Disease-19 case in Indonesia on 
March 2, 2020, has been declared a global pandemic because it has spread to various countries since January 2020, so the market responded and showed panic due to the declaration of the first Coronavirus Disease-19 case.

The trading volume operation pre and post the declaration of the first case of Coronavirus Disease-19 in Indonesia, however, was very different had an Asymp significance value. Sig. (2tailed) of 0.021 less than 0.05 or $<5 \%$, which means that the hypothesis shows that there is information content related to trading volume activity as a result, abnormal returns for all firms differed pre and post the first Coronavirus Disease-19 case was announced in Indonesia. In 2020, the research hypothesis, or $\mathrm{H}_{2}$, will be listed on the Indonesia Stock Exchange, and the research hypothesis or $\mathrm{H}_{2}$ is "supported". In line with research conducted by (Febriyanti, 2020), it is stated that there is a significant difference in trading volume activity before and after the announcement of the first case of Covid-19 patients in Indonesia. These results imply that the market gave unfavorable signals to investors after the announcement of the first case of Covid19 patients in Indonesia so that it tends to cause the LQ-45 company's stock price to decline and tends to result in investors selling shares of LQ-45 companies.

The difference in stock market volume activity pre and post the declaration of the first Coronavirus Disease-19 case in Indonesia is important, with trading volume activity increasing post the declaration. A sharp market reaction, where many investors were concerned about stock prices falling in sub-sectors of companies listed on the IDX, was one of the factors causing the difference in trading volume activity pre and post the declaration of the inaugural Coronavirus Disease-19 case in Indonesia. Since many investors sell their shares, stock prices have fallen and share market activity has risen, implying that the number of shares exchanged has increased.

\section{Conclusion}

The results of this study indicate that there are differences in abnormal returns and trading volume activity which are statistically significant pre and post the event. There is a difference in the trading volume activity of shares between pre and post the declaration, and there is an increase in trading volume activity post the declaration of the first Coronavirus Disease-19 case in Indonesia. So it can be concluded that the declaration contains information because most investors responded to the Coronavirus Disease-19 incident.

\section{References}

Al-Awadhi, A. M., Alsaifi, K., Al-Awadhi, A., \& Alhammadi, S. (2020). Death and contagious infectious diseases: Impact of the COVID-19 virus on stock market returns. Journal of behavioral and experimental finance, 27, 100326.

Atahau, A. D. R., \& Sakti, I. M. (2020). REAKSI PASAR MODAL ATAS PEMBERLAKUAN PSBB DI TENGAH PANDEMI COVID 19 (Studi Kasus Perusahaan Sub Sektor Hotel, Restoran dan Pariwisata di BEI). Journal of Banking and Financial Technology, 1(2), 58-66.

Broadstock, D. C., Chan, K., Cheng, L. T., \& Wang, X. (2021). The role of ESG performance during times of financial crisis: Evidence from COVID-19 in China. Finance research letters, 38, 101716. 
Febriyanti, G. A. (2020). Dampak pandemi Covid-19 terhadap harga saham dan aktivitas volume perdagangan (Studi kasus saham LQ-45 di Bursa Efek Indonesia). Indonesia Accounting Journal, 2(2), 204-214.

Hindayani, N. (2020). Analisis Reaksi Pasar Saham Atas Peristiwa Covid-19 Di Indonesia. Jurnal IImiah MEA (Manajemen, Ekonomi, \& Akuntansi), 4(3), 1645-1661.

Indarti, I., \& Purba, D. M. B. (2011). Analisis perbandingan harga saham dan volume perdagangan saham sebelum dan sesudah stock split. Jurnal Ilmiah Aset, 13(1), 57-63.

Sambuari, I. B., Saerang, I. S., \& Maramis, J. B. (2020). Reaksi Pasar Modal Terhadap Peristiwa Virus Corona (Covid-19) Pada Perusahaan Makanan Dan Minuman Yang Terdaftar Di Bursa Efek Indonesia. JMBI UNSRAT (Jurnal IImiah Manajemen Bisnis dan Inovasi Universitas Sam Ratulangi)., 7(3).

Sugiyono, P. D. (2017). Metode Penelitian Bisnis: Pendekatan Kuantitatif, Kualitatif, Kombinasi, dan R\&D. Penerbit CV. Alfabeta: Bandung.

Sumiari, K. N., \& Putri, W. T. I. (2020). Reaksi Pasar Terhadap Pengumuman Covid-19 di Indonesia. Jurnal Bisnis dan Kewirausahaan, 16(3), 232-236.

Suwardjono. (2010). Teori Akuntansi : Pengungkapan dan Sarana Interpretatif (Edisi Ketiga). BPFE 